\title{
Etnomatematika pada Pembuatan Batu Bata Merah Masyarakat Dusun Bayat Wringinpitu Banyuwangi sebagai Lembar Kerja Siswa
}

Author:
Rakha Dhiya Dinata ${ }^{1}$
Toto' Bara Setiawan ${ }^{1}$
Dinawati Trapsilasiwi ${ }^{1}$
Affiliation:
${ }^{1}$ Mathematics Education,
University of Jember, East
Java, Indonesia
Corresponding author:
Rakha Dhiya Dinata,
rakhaddinata@ gmail.com
Dates:
Received: $10 / 4 / 2021$
Accepted: $1 / 7 / 2021$
Published: $9 / 7 / 2021$

\begin{abstract}
Abstrak. Etnomatematika merupakan sebuah kegiatan yang dilakukan oleh sekelompok budaya dimana tanpa mereka sadari telah menerapkan konsep matematika. Dalam hal ini etnomatematika merupakan jembatan antara matematika dan budaya. Penelitian ini bertujuan untuk mendeskripsikan etnomatematika pada pembuatan batu bata merah Dusun Bayat Wringinpitu Banyuwangi dengan menghasilkan suatu Lembar Kerja Siswa (LKS). Subjek penelitian adalah 3 orang pembuat batu bata merah Dusun Bayat. Jenis penelitian ini adalah penelitian kualitatif dengan pendekatan etnografi. Metode pengumpulan data yang digunakan yaitu observasi dan wawancara. Hasil dari penelitian ini menunjukkan bahwa adanya konsep matematika pada pembuatan batu bata merah meliputi konsep menghitung, mengukur, membilang, mendesain, kesebangunan dan kekongruenan, segmen garis, bangun datar dan bangun ruang.
\end{abstract}

Kata kunci: Etnomatematika, Pembuatan Batu Bata Merah, Lembar Kerja Siswa.

\begin{abstract}
Ethnomatematics is an activity carried out by a group of cultures which without realizing it has applied mathematical concepts. In this case ethnomatematics is a bridge between mathematics and culture. This study aims to describee ethnomatematics in the manufacture of red bricks in Bayat Wringinpitu Banyuwangi by producing a Student Worksheet. Research subjects are 3 red brick makers in Bayat. This type of research is qualitative research with an ethnographic approach. Data collection methods used were observation and interviews. The results of this study indicate that the existence of mathematical concepts in the manufacture of red bricks includes the concepts of counting, measuring, numerating, designing, congruency, line segments, plane figure and solid figure.
\end{abstract}

Keywords: Ethnomatematics, red brick maker, students worksheet

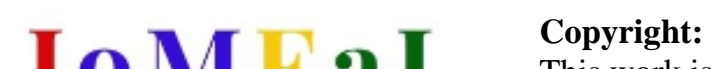 \\ This work is licensed under a Creative Commons Attribution-ShareAlike 4.0 International License. \\ Read online: \\ https://jurnal.unej.ac.id/index.php/JOMEAL/index or scan barcode beside.}

\section{How to cite this article:}

Dinata, R., Setiawan, T., \& Trapsilasiwi, D. (2021). Etnomatematika pada Pembuatan Batu Bata Merah Masyarakat Dusun Bayat Wringinpitu Banyuwangi sebagai Lembar Kerja Siswa. Journal of Mathematics Education and Learning, 1(2), 98-108. Retrieved from https://jurnal.unej.ac.id/index.php/JOMEAL/article/view/24241 


\section{Pendahuluan}

Budaya atau kebudayaan berasal dari bahasa sansekerta yaitu buddhayah bentuk jamak dari buddi (budi atau akal) diartikan sebagai hal-hal yang berkaitan dengan budi dan akal manusia. Dengan demikian kebudayaan dapat diartikan sebagai hal-hal yang bersangkutan dengan akal. Kebudayaan adalah kompleks keseluruhan yang mencakup di dalam pengetahuan, kepercayaan, seni, moral, hukum, adat istiadat, dan kecakapan serta kebiasaan-kebiasaan lain yang dibutuhkan oleh manusia sebagai warga masyarakat (Nurhalimah, 2015)..

Matematika merupakan ilmu pengetahuan yang diperoleh dengan bernalar (Suherman, 2001). Matematika merupakan ilmu dasar dari setiap ilmu pengetahuan (Ag, Moch dkk 2008). Matematika mempunyai peran yang sangat penting dan menjadi aspek universal dalam kehidupan sehari hari. Dalam dunia pendidikan matematika kerap dianggap mata pelajaran yang sulit, hal ini karena pembelajaran matematika disekolah terlalu formal, tidak seperti matematika yang dilakukan seharihari. Dalam kegiatan sehari-hari ilmu matematika yang berkaitan dengan kebudayaan biasa disebut dengan istilah etnomatematika.

Etnomatematika merupakan jembatan antara matematika dan budaya. Etnomatematika yaitu studi tentang matematika yang memperhitungkan budaya, dimana matematika muncul dengan memahami penalaran dan sistem matematika yang digunakan (D'Ambrosio, 1985). Etnomatematika adalah bentuk matematika yang dipengaruhi atau didasarkan pada budaya. Melalui penerapan etnomatematika dalam pendidikan khususnya pendidikan matematika, diharapkan siswa lebih memahami matematika dan budaya mereka, serta para pendidik lebih mudah untuk menanamkan nilai budaya itu sendiri dalam diri siswa, sehingga nilai budaya yang merupakan bagian karakter bangsa tertanam sejak dini dalam diri siswa (Wahyuni, dkk, 2013). Menurut Arwanto (2017) etnomatematika merupakan studi tentang ide-ide matematika dari masyarakat tradisional yang diterapkan dalam masyarakat tertentu. Etnomatematika juga matematika budaya yang diterapkan dan dipraktikkan oleh kelompok oleh masyarakat pedesaan, perkotaan, kelompok buruh, anak-anak dari kelompok usia tertentu, masyarakat, dan lain sebagainya. Berdasarkan penjelasan terkait dengan etnomatematika dapat disimpulkan yaitu kebudayaan yang dilakukan dalam kegiatan sehari-hari yang berkaitan dengan matematika.

Keanekaragaman budaya di Indonesia tidak jauh dari matematika, karena Indonesia salah satu negara kepulauan. Salah satu daerah yang memiliki keanekaragaman yaitu Kabupaten Banyuwangi. Kabupaten Banyuwangi memiliki tiga suku, yaitu suku Osing, suku Jawa, dan beberapa suku Madura. Banyuwangi juga memiliki banyak budaya dalam kepercayaan, tari- tarian, makanan, adat istiadat, dan masih banyak lagi yang lainya. Kabupaten Banyuwangi memiliki kerajinan tangan seperti anyaman tangan bambu suku osing yang terletak di Gintangan, anyaman topi dari batang daun gebang, dan ada lagi sentra pembuatan batako yang banyak ditemukan di wilayah Kaliputih Genteng, Industri pembuatan Paving press mesin yang ada di Mangir Rogojampi, dan pembuat kerajinan batu bata merah secara manual atau tradisional yang ada di daerah Dusun Bayat Wringinpitu Kecamatan Tegaldlimo.

Daerah yang dipilih dalam penelitian adalah Dusun Bayat Desa Wringinpitu, Kecamatan Tegaldlimo, Kabupaten Banyuwangi, karena termasuk dalam salah satu tempat produksi kerajinan tangan, khususnya dalam pembuatan batu bata merah secara tradisional yang cukup terkenal di Banyuwangi. Pembuat batu bata merah di daerah Dusun Bayat Wringinpitu Banyuwangi melakukan proses pembuatan dengan cara tradisional. Tanpa disadari pembuat batu bata merah telah 
menggunakan konsep matematika dalam membuat batu bata merah. Pada saat pembuatan batu bata merah terdapat aktivitas menghitung, mengukur, membilang, mendesain, konsep kesebangunan dan kekongruenan, konsep segmen garis, konsep bangun datar dan bangun ruang. Hal ini sama dengan penelitian yang relevan telah dilakukan sebelumnya oleh (Rohmadiana, 2017) dengan judul "Etnomatematika pada Aktivitas Tukang Bangunan Masyarakat Jawa di Desa Kencong" dan kemudian dikembangkan yang menghasilkan konsep segmen garis, bangun ruang dan bangun datar. Hasil dari penelitian ini menggunakan konsep matematika di dalam aktivitasnya, yaitu konsep mengukur, menghitung, membilang, mendesain. Dari konsep matematika tersebut terdapat materi matematika sehingga dapat dijadikan sebagai soal. Berdasarkan aktivitas matematika pada penelitian tersebut, maka dibuat produk berupa Lembar Kerja Siswa (LKS). Lembar Kerja Siswa (LKS) yang dihasilkan menggambarkan beberapa etnomatematika pada pembuatan batu bata merah. Pada LKS ini materi yang akan diangkat setelah penelitian adalah perbandingan. Soal dan pembahasan yang dibuat merupakan aplikasi dari penerapan etnomatematika pada pembuatan batu bata merah Dusun Bayat Wringinpitu Banyuwangi. Aktivitas yang pertama pada LKS yaitu mengamati, aktivitas kedua adalah menanya, aktivitas ketiga adalah mencoba, aktivitas keempat yaitu menganalisis, dan aktivitas yang terakhir yaitu mengkomunikasikan.

Berdasarkan uraian di atas, maka dilakukan penelitian tentang etnomatematika yang ada pada pembuatan batu bata merah dengan tujuan mendeskripsikan etnomatematika pada pembuatan batu bata merah dan membuat lembar kerja siswa sebagai produk penelitian terkait dengan etnomatematika pada pembuatan batu bata merah Dusun Bayat Wringinpitu Banyuwangi. Oleh karena itu, diangkat sebuah judul penelitian yakni "Etnomatematika Pada Pembuatan Batu Bata Merah Masyarakat Dusun Bayat Wringinpitu Banyuwangi Sebagai Lembar Kerja Siswa ”.

\section{Metode Penelitian}

Penelitian ini merupakan penelitian kualitatif dengan pendekatan etnografi yang digunakan untuk menggambarkan memahami teorema tentang apa saja yang dialami oleh subjek penelitian misalnya perilaku, presepsi, motivasi, tindakan, dan lain-lain yang terdapat pada pembuatan batu bata merah. Daerah penelitian yang digunakan dalam penelitian ini adalah Dusun Bayat Desa Wringinpitu Kecamatan Tegaldlimo Kabupaten Banyuwangi Jawa Timur. Subjek penelitian yaitu Yanto, Saimin, dan Siti Solehah yang merupakan pembuat batu bata merah.

Tahap pertama yang harus dilakukan yaitu pendahuluan dimana pada tahap ini yang dilakukan adalah memilih daerah dan subjek penelitian. Tahap kedua adalah pembuatan instrumen, yang dilakukan pada tahap ini adalah memvalidasi instrumen pedoman wawancara dan observasi kepada validator. Tahap selanjutnya yaitu pengambilan data, pada penelitian ini pengumpulan data diperoleh dengan melakukan observasi, wawancara pada proses pembuatan batu bata merah.

Observasi dilakukan dengan mengamati secara langsung proses pembuatan batu bata merah. Wawancara dilakukan kepada pembuat batu bata merah untuk memperoleh data atau informasi sebanyak dan sejelas mungkin. Tahap selanjutnya adalah analisis data, langkah ini dilakukan dengan menyusun data sesuai kajian masalah dan tujuan penelitian yaitu aktivitas menghitung, mengukur, membilang, mendesain, konsep garis, bangun datar dan bangun ruang, konsep kesebangunan dan kekongruenan. Tahap akhir adalah penarikan kesimpulan dari hasil data yang diperoleh pada tahap sebelumnya. Tahap pembuatan Lembar Kerja Siswa dilakukan penyusunan dari hasil etnomatematika pada pembuatan batu bata merah masyarakat Dusun Bayat Wringinpitu Banyuwangi. 
Langkah-langkah yang dilakukan untuk mencapai tujuan dalam penelitian ini dapat dilihat pada Gambar 1 sebagai berikut.

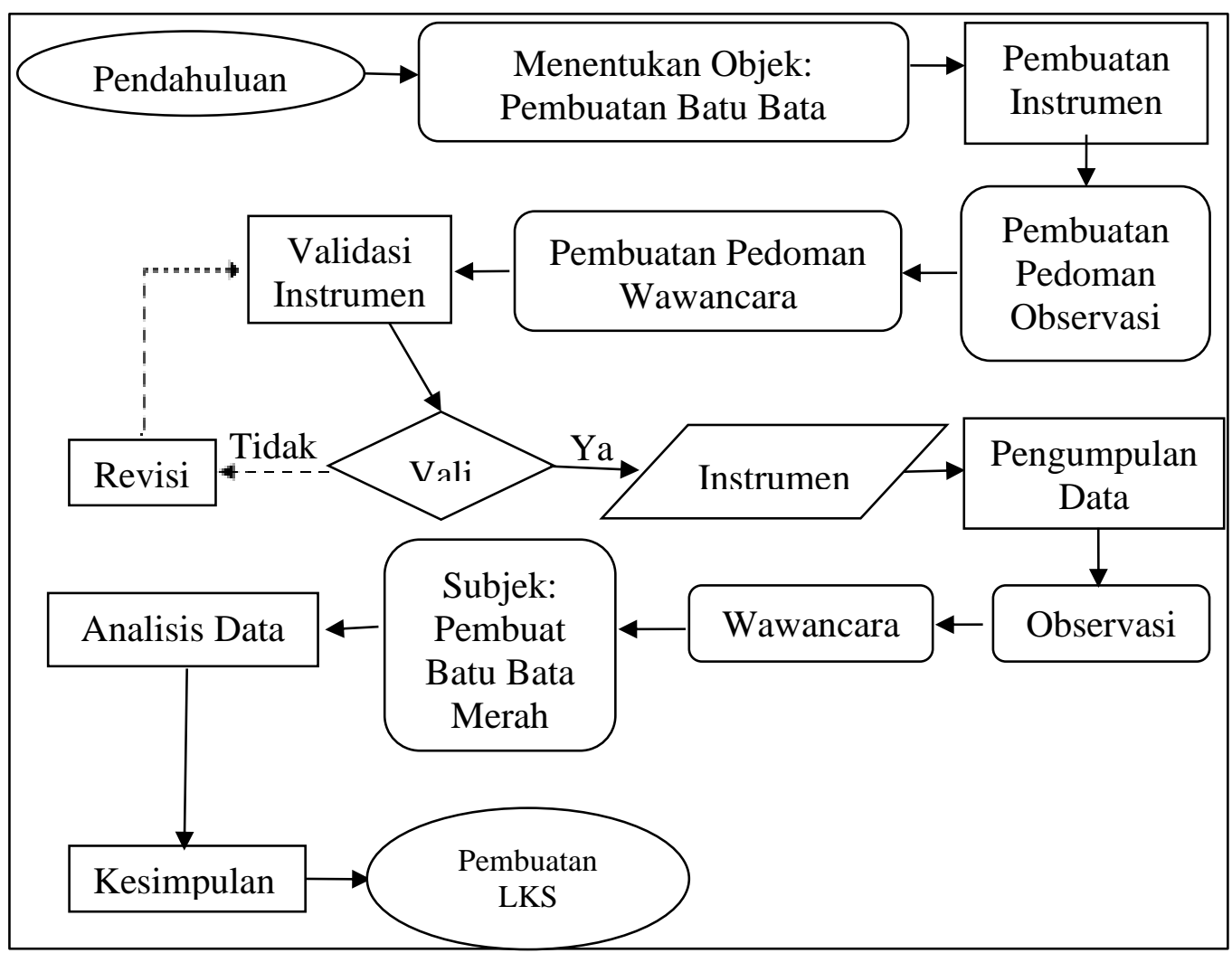

Gambar 1. Prosedur Penelitian

\section{Hasil dan Pembahasan}

Berdasarkan hasil observasi dan wawancara dengan Yanto, Saimin, Siti Soleha yang merupakan subjek penelitian, terdapat etnomatematika pada pembuatan batu bata merah Dusun Bayat Wringinpitu Banyuwangi yaitu aktivitas menghitung, aktivitas mengukur, aktivitas membilang, aktivitas mendesain, konsep segmen garis, bangun datar dan bangun ruang konsep kesebangunan dan kekongruenan.

\section{A. Aktivitas Menghitung}

Aktivitas menghitung terdapat pada pembuat menentukan banyaknya tanah liat dalam sekali pembuatan. Pembuat memiliki acuan tersendiri dalam sekali pembuatan, jika ingin membuat 5.0006.000 batu bata merah maka pembuat membeli tanah menggunakan mobil dam truk seharga $R p .400 .000$ - $R p .450 .000$, sedangkan jika ingin membuat 2.000-2.500 batu bata merah maka pembuat membeli dengan mobil grandong (mobil diesel rakitan) seharga $R p .200 .000-R p .250 .000$. Apabila pembuat ingin membuat batu bata merah dengan jumlah banyak, maka pembuat membeli menggunakan mobil dam truk sehingga biaya yang dikeluarkan lebih sedikit.

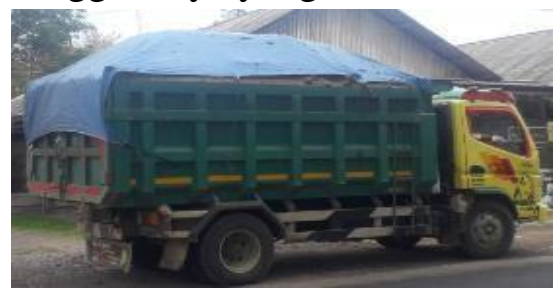




\section{Gambar 2. Mobil Dam Truck}

Aktivitas menghitung selanjutnya muncul saat pembuat melakukan perendaman tanah dengan air. Dalam hal ini pembuat menghitung waktu yang diperlukan untuk sekali perendaman, jika dalam perendaman membutuhkan waktu 3-4 jam. Pembuat melakukan proses penggilingan dengan menambahkan air agar cepat dalam proses pencampuran. Etnomatematika yang terdapat pada aktivitas menghitung lama perendaman adalah operasi. Pada materi operasi hitung bisa dilihat dari volume air yang dibutuhkan untuk sekali perendaman. Jika menggunakan satuan 1 dam truck tanah bisa dihitung berapa liter air yang dibutuhkan. Sehingga banyak sekali operasi hitung yang terdapat pada proses perendaman tanah ini.

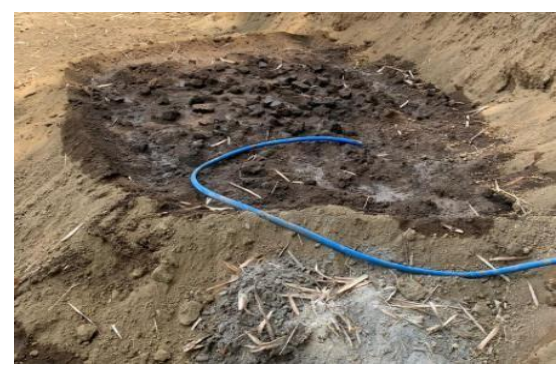

Gambar 3. Perendaman Tanah dengan Air

Pada proses pengeringan terdapat etnomatematika menghitung waktu pengeringan kurang lebih 9-15 jam. Jika cuaca cerah proses pengeringan membutuhkan waktu yang cepat dan sebaliknya jika cuaca mendung bisa kurang lebih sehari semalam. Pembuat tidak mengacu pada waktu dalam proses pengeringan, melainkan mengacu pada cuaca.

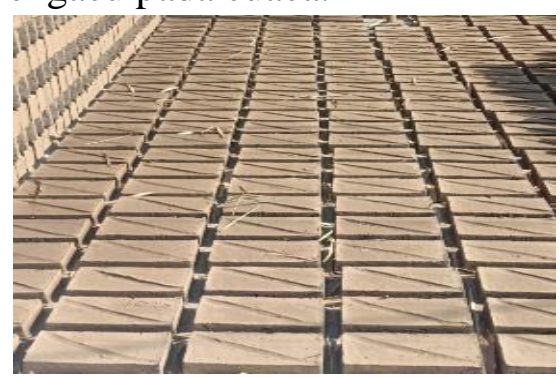

Gambar 4. Pengeringan Batu Bata Merah

Etnomatematika lainnya juga muncul pada saat pembuat memperkirakan jumlah sekam dan kayu bakar untuk melakukan proses pembakaran. Untuk menghitung banyak kayu bakar yang dibutuhkan memiliki acuan yaitu 4-5 pick up untuk membakar 36.000 batu bata merah sedangkan untuk sekamnya membutuhkan 65-95 sak (karung). Berdasarkan hal tersebut maka etnomatenatika yang terdapat pada aktivitas memperkirakan banyak kayu bakar dan sekam adalah operasi hitung dan perbandingan senilai.

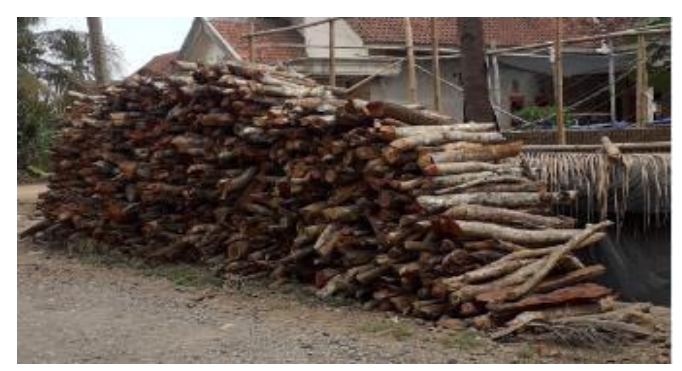

Gambar 5. Kayu Bakar 


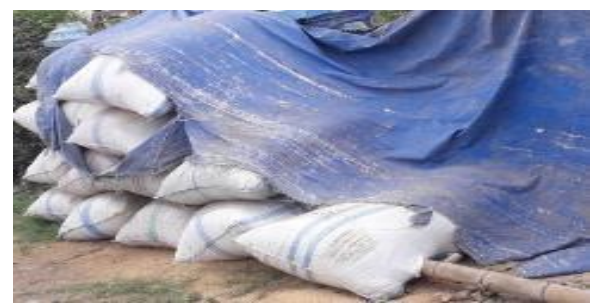

Gambar 6. Sekam

Pada proses pembakaran terdapat etnomatematika yang muncul yaitu aktivitas menghitung lama yang dibutuhkan pada proses pembakaran. Menurut hasil penelitian, menghitung lama poses pembakaran membutuhkan waktu kurang lebih 12-24 jam tergantung dari banyaknya batu bata merah. Jika ingin membutuhkan waktu yang singkat dalam proses pembakaran, maka dibutuhkan lebih banyak bahan bakar yang diperlukan. Etnomatematika yang terdapat pada aktivitas menghitung lama pembakaran adalah operasi hitung dan perbandingan berbalik nilai. Salah satu operasi hitung yang terdapat yaitu meghitung volume sekam yang dibutuhkan, sudah diketahui banyaknya sekam yang dibutuhkan yaitu sekitar 65-95 sak(karung), sedangkan ukuran $s a k$ (karung) yaitu $75 \mathrm{~cm} \times 115 \mathrm{~cm}$ sehingga dapat dicari volume sekam yang dibutuhkan pada saat proses pembakaran.

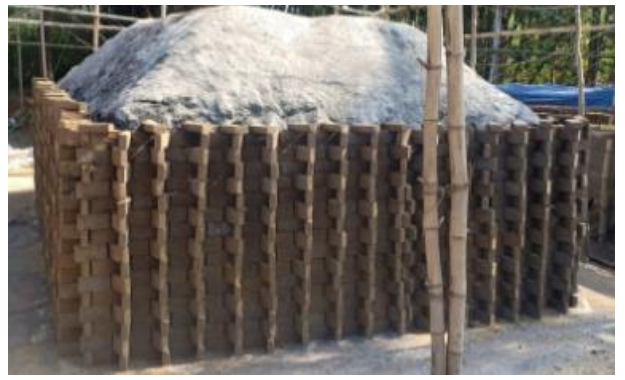

Gambar 7. Proses Pembakaran Batu Bata Merah

Pada aktivitas menghitung berikutnya muncul pada saat menghitung banyak batu bata merah berdasarkan pola tumpukan. Berdasarkan hasil penelitian pembuat dalam menghitung batu bata merah dalam tumpukan. Hal tersebut dilakukan untuk mempermudah menghitung batu bata merah yang telah jadi dan siap untuk dipasarkan. Hal ini sesuai dengan aktivitas menghitung muncul pada saat menghitung dengan sistem satu persatu dengan ditata rapi (Lestari, dkk, 2019). Berdasarkan hal tersebut, etnomatematika yang terdapat pada kegiatan menghitung batu bata merah berdasarkan penataan adalah operasi hitung. Salah satu operasi hitung yang dihasilkan yaitu dapat menghitung volume batu bata dalam sekali produksi. Jika ukuran satu batu bata merah yaitu $22 \mathrm{~cm} \times 10 \mathrm{~cm} \times 5 \mathrm{~cm}$ dan dalam satu kali produksi bisa menghasilkan 36.000 batu bata merah, maka total volume batu bata merah yang dihasilkan yaitu $39,6 \mathrm{~m}^{3}$

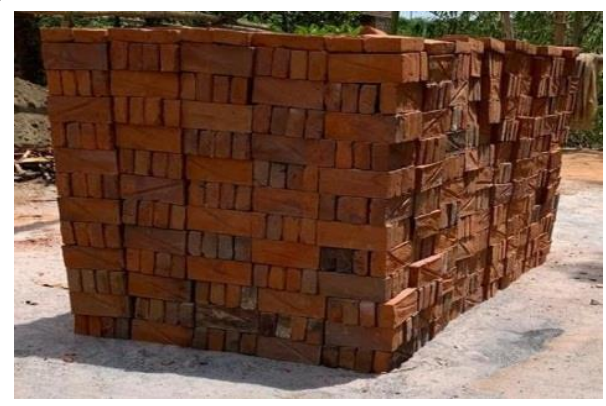




\section{B. Aktivitas Mendesain}

Gambar 8. Penataan Batu Bata Merah Berdasarkan Pola

Aktivitas matematika mendesain muncul pada saat proses pembuatan lubang perendaman. Dalam proses ini pembuatan tempat perendaman dengan air. Tahap awal yang dilakukan ialah dengan cara melubangi lahan dengan bentuk ngotak (kotak) kemudian tanah dimasukkan ke dalam lubang dan dicampur dengan air. Namun, untuk saat ini pembuat sudah tidak memakai cara seperti itu karena tanah yang mereka gunakan memiliki jumlah sedikit yang mengharuskan pembuat batu bata merah membeli tanah. Kemudian tanah yang baru dibeli ditumpuk seperti tumpukan tanah menggunung kira-kira dengan membentuk bangun kerucut yang bagian atasnya dipotong sehingga tumpul.

Pada aktivitas mendesain selanjutnya muncul saat pembuatan cetakan batu bata merah. Cetakan yang digunakan memiliki bentuk balok dengan tambahan sisi atas dan samping kanan bangun datar trapesium, sebagaimana berfungsi untuk pegangannya. Hasil dari cetakan tersebut adalah batu bata merah dengan bentuk balok. Etnomatematika yang terdapat pada kegiatan ini adalah konsep mendesain bangun ruang dan bangun datar.

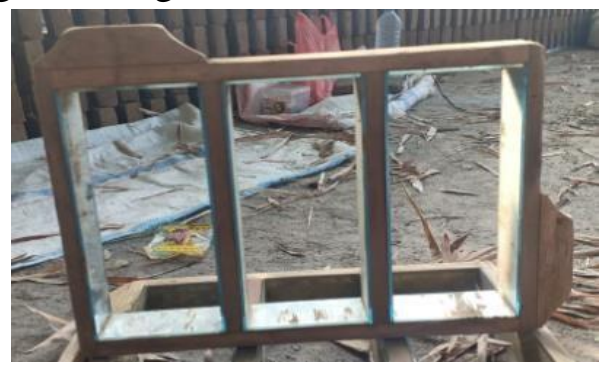

Gambar 9. Cetakan Batu Bata Merah

Selanjutnya aktivitas mendesain terdapat pada saat pembuat pagar disekeliling tempat pembakaran. Pada kegiatan ini pembuat hanya menumpuk batu bata merah dengan cara dimiringkan kemudian ditumpuk menyilang. Untuk sekali membuat amping-amping (pagar disekelilingnya) membutuhkan sekitar 2.000-2.300 biji batu bata merah. Jenis tumpukan ini merupakan desain tumpukan yang paling kuat karena antar satu batu bata dengan yang lain dikunci. Etnomatematika yang terdapat pada kegiatan ini adalah mendesain dan menghitung karena terdapat materi matematika pola barisan dan deret.

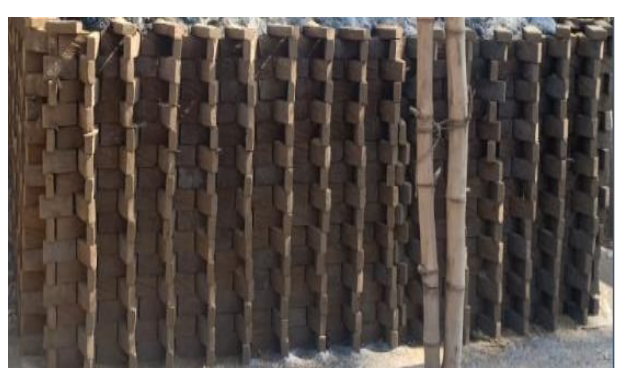

Gambar 10. Pagar Sekeliling Pembakaran

Pada saat pembuat melakukan penataan dan penumpukan terdapat etnomatematika yang muncul yaitu aktivitas mendesain. Dalam menumpuk dan menata batu bata merah pembuat menggunakan cara menumpuk batu bata merah dengan 4 tumpukan miring dan 4 tumpukan lurus. Hal ini bertujuan untuk memudahkan pada saat pengambilan dan penghitungan. 


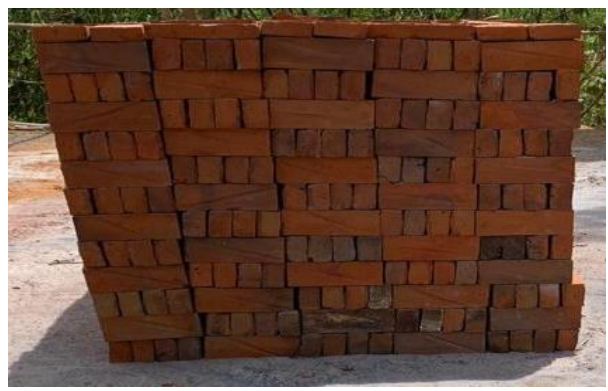

Gambar 11. Penataan dan Penumpukan Batu Bata Merah

\section{Aktivitas Mengukur}

Pada proses sebelum pencetakan batu bata merah pastinya membutuhkan cetakanya, aktivitas mengukur ini muncul pada saat pembuat batu bata merah mengukur ukuran cetakan batu bata merah yang akan digunakan. Pada cetakan yang digunakan pembuat memiliki ukuran standar yaitu $22 \mathrm{~cm} \times 10 \mathrm{~cm} \times 5 \mathrm{~cm}$. Etnomatematika yang terdapat pada kegiatan ini adalah pengukuran.

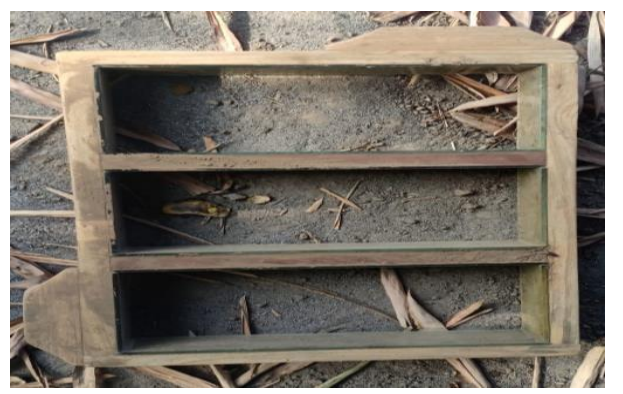

Gambar 12. Ukuran Cetakan Batu Bata Merah

\section{Aktivitas Membilang}

Aktivitas membilang muncul saat pembuat mengambil sekam dan abu dapur etnomatematika muncul pada saat pembuat mengambil sekam dengan satuan kepalan dan timbo (timba). Dalam pencampuran tanah untuk sekali pembuatan batu bata merah memerlukan $1-1 \frac{1}{2}$ timbo (timba) yang mempunyai volume 7,5 liter. Jika menggunakan satuan kepalan tangan (ukuran tak baku), pembuat hanya memakai ilmu kira-kira yang merupakan ilmu approximasi (ilmu perkiraan) saja. Hal ini sesuai tentang aktivitas membilang merupakan cara menyebutkan bilangan tentang banyaknya unsur suatu himpunan yaitu sifat satuaan, duaan, tigaan, dan seterusnya (Damayanti, 2015).

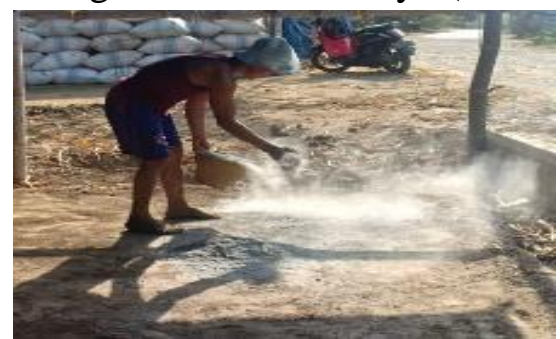

Gambar 13. Pengambilan Sekam dan Abu Dapur

Pada saat proses pencetakan batu bata merah pembuat mengambil adonan tanah didalam timba yang memiliki volume kurang lebih $9500 \mathrm{~cm}^{3}$ menggunakan cawukan (kepalan 2 tangan) sehingga dalam sekali pencetakan batu bata merah pembuat membutuhkan kurang lebih rong cawukan (dua kepalan dua tangan) atau 
kurang lebih 5-6 kepalan tangan saja sehingga 1 ember bisa menghasilkan 8-9 batu bata merah. Etnomatematika yang terdapat pada aktivitas ini yaitu membilang dengan satuan cawukan atau kepalan tangan.

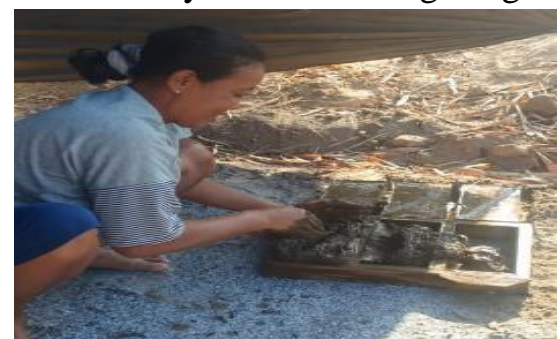

Gambar 14. Mencetak Batu Bata Merah

\section{E. Konsep Segmen Garis}

Aktivitas matematika konsep segmen garis muncul pada saat proses pembuatan motif dari batu bata merah tesebut. Pembuat dalam membuat pola segmen garis menggunakan jari dengan cara menarik garis dari pojok ke pojok sehingga membentuk segmen garis. Coakan ini berfungsi untuk merekatkan antar batu bata merah yang lain. Pada kegiatan ini muncul etnomatematika konsep segmen garis dan grade refleksi (cermin geser) yang dapat dilihat pada saat penarikan coakan segmen garis yang dicerminkan pada batu bata yang lainnya.

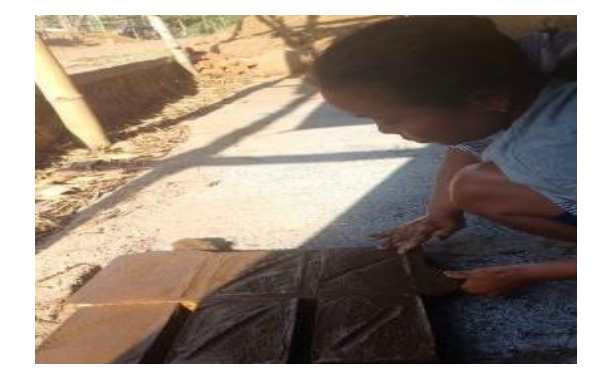

Gambar 15. Pembuatan Motif Coakan

\section{F. Bangun Datar dan Bangun Ruang}

Bangun datar dan bangun ruang muncul pada cetakan batu bata merah yang dibuat. Terdapat bentuk cetakan berupa bangun ruang balok dan bangun datar berupa trapesium yang berfungsi sebagai pegangan dari cetakan batu bata merah tersebut. Bentuk bangun ruang juga terdapat pada hasil dari cetakan batu bata merah berupa bentuk balok dari batu bata merah tersebut.

\section{G. Konsep Kesebangunan dan Kekongruenan}

Pada saat pembuat menumpuk batu bata merah dengan menumpuk batu bata merah yang lainnya dengan pola disigir (ditata miring). Berdasarkan hal tersebut terdapat etnomatematika yaitu konsep kekongruenan dan kesebangunan yang mana ada kaitanya dengan konsep kesebangunan karena kekongruenan pada tumpukan batu bata merah ini dihasilkan dari konsep kesebangunan.

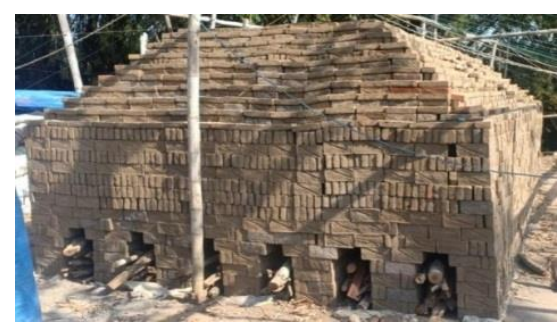

Gambar 16. Penumpukan Sebelum Pembakaran 
Aktivitas kesebangunan muncul saat pembuat membuat lubang tempat memasukkan kayu bakar. Cara membuat lubang tersebut dengan menumpuk saja. Jika pembuat ingin membakar 36.000 batu bata merah maka pembuat membuat 6 lubang tempat memasukkan kayu bakar yang memiliki bentuk sama namun memiliki ukuran berbeda. Etnomatematika yang terdapat pada aktivitas membuat lubang tempat memasukkan kayu bakar adalah konsep kesebangunan.

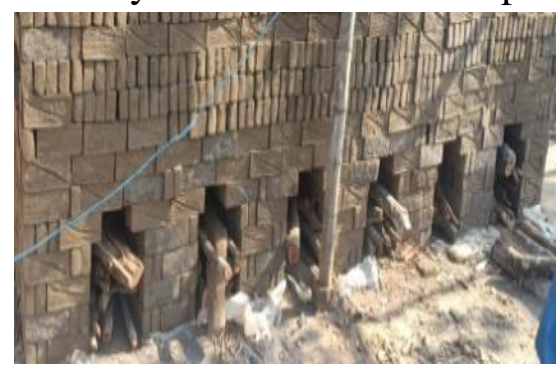

Gambar 17. Lubang Kayu Bakar

\section{H. Lembar Kerja Siswa}

Hasil dari penelitian ini dibuat produk berupa Lembar Kerja Siswa (LKS). LKS berupa bahan cetak yang dapat digunakan untuk membantu siswa belajar secara terprogram dan terarah (Kholilah, dkk, 2016). Lembar Kerja Siswa merupakan lembaran-lembaran yang berisi tugas yang harus dikerjakan serta diselesaikan oleh peserta didik. Lembar Kerja Siswa biasanya berupa petunjuk, langkah-langkah pengerjaan tugas. Tugas yang diperintahkan dalam LKS harus sesuai dengan kompetensi dasar yang akan dicapai (Majid, 2011). Berdasarkan hasil penelitian, maka pokok bahasan yang akan diangkat yaitu indikator-indikator yang dapat teramati dengan baik dan bisa diterapkan dalam perhitungan serta konsep matematika yang jelas. Pada LKS ini pokok bahasan materi yang akan diangkat adalah perbandingan. Soal dan pembahasan yang dibuat merupakan aplikasi dari penerapan etnomatematika pada pembuatan batu bata merah dusun Bayat Wringinpitu Banyuwangi. Diharapkan dengan adanya LKS ini dapat meningkatkan pemahaman siswa terhadap materi perbandingan.

\section{Kesimpulan}

Berdasarkan hasil dan pembahasan, terdapat beberapa etnomatematika pada pembuatan batu bata merah. Etnomatematika yang terdapat pada aktivitas menghitung muncul pada saat pembuat menghitung banyaknya tanah yang akan digunakan untuk membuat batu bata merah, menghitung lama perendaman tanah dengan air, menghitung lama proses pengeringan, memperkirakan jumlah sekam dan kayu bakar, proses pembakaran, menghitung banyaknya batu bata merah berdasarkan pola tumpukan. Aktivitas mendesain muncul pada saat pembuat membuat lubang perendaman berbentuk ngotak (kotak), membuat cetakan batu bata merah berbentuk balok dengan pegangan trapesium, membuat pagar disekeliling batu bata merah yang akan dibakar, proses penataan dan tumpukan batu bata merah. Aktivitas mengukur muncul pada saat menentukan ukuran dari cetakan batu bata merah, yaitu dengan ukuran standar $22 \mathrm{~cm} \times 10 \mathrm{~cm} \times 5 \mathrm{~cm}$. Aktivitas membilang muncul pada saat pembuat mengambil sekam dan abu dapur, pada saat akan melakukan pencetakan dengan mengambil adonan menggunakan satuan kepalan. Etnomatematika juga terdapat pada aktivitas pembuat dalam membuat coakan pada batu bata merah, dalam kegiatan ini muncul etnomatematika konsep segmen garis. Etnomatematika muncul pada bentuk dari cetakan batu bata merah yaitu 
bangun ruang dan bangun datar berupa balok dan trapesium, sedangkan batu bata yang di hasilkan terdapat etnomatematika berupa bangun ruang karena batu bata merah berbentuk balok. Etnomatematika selanjutnya muncul pada saat pembuat menumpuk batu bata merah dimana pembuat hanya menata dengan cara disigir ditata miring saja, dalam hal itu terdapat etnomatematika konsep kekongruenan. Konsep kesebangunan muncul pada saat pembuat membuat lubang memasukkan kayu bakar. Konsep bangun datar berupa balok dari batu bata yang dihasilkan. Lembar Kerja Siswa (LKS) akan dibuat menjadi beberapa (LKS) dengan topik etnomatematika pada pembuatan batu bata merah masyarakat dusun Bayat Wringinpitu Banyuwangi dengan materi yang banyak muncul yaitu perbandingan senilai dan berbalik nilai untuk kelas VII SMP Kurikulum 2013 dan volume bangun sisi datar (balok) untuk kelas VIII SMP Kurikulum 2013.

\section{Daftar Pustaka}

Ag, M. M dan Fathani, A. H. (2008). Mathematical Intelegence. Yogyakarta: AR-Ruzz Media.

Arwanto. (2017). Eksplorasi Etnomatematika Batik Trusmi Cirebon untuk Mengungkap Nilai Filosofi dan Konsep Matematis. Jurnal Pendidikan MIPA, 7(1), 40-49.

D'Ambrosio, U. (1985). Etnomatematics and its place in the history and pedagogy of matematics. For Learning of Mathematics, 5(1), 44-48.

Damayanti, Y. N. (2015). Peningkatan Kemampuan Membilang Melalui Media Kartu Bergambar Pada Anak Kelompok B1 TK PKK 37 Dodogan Jatimulyo Dlingo Bantul. Skirpsi. Yogyakarta: Universitas Negeri Yogyakarta.

Kholilah, Y. N., Mahardika, I. K., \& Sutarto. (2016). Kelayakan Lembar Kerja Siswa (LKS) Berbasis Proyek untuk Pembelajaran IPA di SMP. Jurnal Pembelajaran dan Pendidikan Sains, 1(1), 1-8.

Lestari, N, dkk. (2019). Etnomatematika pada Proses Penetasan Telur Penyu Hijau Semi Alami di Sukamade, Taman Nasional Meru Betiri sebagai Bahan Ajar Siswa Berbasis Fraktal. Jurnal Pendidikan MIPA dan MIPA. 21(1).

Majid, A. (2011). Perencanaan Pembelajaran Mengembangkan Standar Kompetensi Guru. Bandung: PT Remaja Rosdakarya.

Nurhalimah. (2015). Upaya Dinas Kebudayaan Pariwisata Pemuda dan Olahraga Dalam Menyelenggarakan Kegiatan Bidang Kebudayaan di Kabupaten Nunukan. eJournal Ilmu Pemerintahan.3, (1) 2015 : 239-252.

Rohmadina, F. A. (2017). Etnomatematika Pada Aktivitas Tukang Bangunan Masyarakat Jawa di Desa Kencong. Skripsi. Jember: Universitas Jember.

Suherman. E. (2001). Pembelajaran Matematika Kontemporer. Bandung: JICA.

Wahyuni, A. dan Dkk. (2013). Peran etnomatematika dalam membangun karakter bangsa. Jurnal Seminar Nasional Matematika Dan Pendidikan Matematika FMIPA UNY. 